\title{
LIVE IN DESTINY OR DIE AS MARTYR The Venture of Front Pembela Islam (FPI) in Contemporary Indonesia
}

\author{
M. Ridlwan Nasir \\ IAIN Sunan Ampel, Surabaya, Indonesia
}

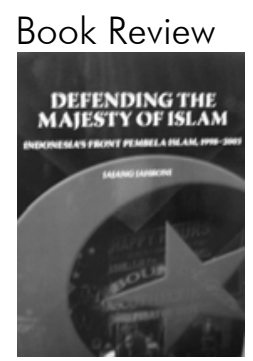

\begin{tabular}{|c|c|}
\hline Book title & $\begin{array}{l}\text { Defending the Majesty of Islam: Indonesia's } \\
\text { Front Pembela Islam, 1998-2003 }\end{array}$ \\
\hline Author & : Jajang Jahroni \\
\hline No. of Pages & $\mathrm{vii}+72$ \\
\hline Year & : 2008 \\
\hline Publisher & University of Washington Press \\
\hline
\end{tabular}

This book aims at providing a succinct socio-historical analysis of radical Islamist movement in post-New Order Indonesia (1998-2003), with particular focus on Front Pembela Islam (FPI, Islamic Defenders Front). It covers the roots, development and manifestation of radical Islamist activism of FPI from various perspectives such as history, socio-economy and politics. As represented by the title, 'Defending the Majesty of Islam' as the slogan of the FPI, the author wishes to shed some lights on the importance of ideology for social-religious movements despite the fact that he also appreciates the significance of aspects outside of ideology.

By and large, this study is divided into five main parts. The first part deals with an examination of the interplay of several factors leading to the emergence of various 'indigenous' Islamist movements, such as socio-political circumstances of Indonesia's regimes, modernization, global politics, and the growth of an educated urban 
population. The second part relates the emergence of FPI with the biography of its founding father, Muhammad Rizieq Syihab. This part gives prelude to the emergence of FPI. The third part copes with the creation of FPI and its paramilitary wing and activities. The fourth part provides the analysis of FPI's ideology with particular reference to the goal of establishing Islamic law in Indonesia. The last part examines FPI's organizational structure and social bases, recruitment practices, and training methods, as well as its vigilant acts in implementing its ideology.

One of the underlying assumptions developed throughout the work is that religion-based radicalism in Indonesia, as anywhere else in the rest of Muslim world, is triggered mainly by the Muslims' failure to come to terms with modernity and the process of modernization ( $p$. $11+58)$. He also argues that a number of events taking place in the Muslim world, such as the 1979 Islamic revolution in Iran, contribute to the making of radical Islamism in Indonesia, including the FPI (p. 9). In some occasions, FPI is also active in responding the global political issues. Given its international responsiveness, he asserts that there is no Middle-eastern connection whatsoever behind its existence (p. 23). The raison d'étre of FPI is local par excellence; its rationale is authentically 'Indonesian' in that it was founded to respond to local issues in public sphere. The international issues merely occupy the peripheral mindset of FPI.

Through this book, the author presents a great deal of interesting issues behind the phenomenon of FPI activisms. One of the issues he raised is the alleged support given by some high-ranking military officials to the existence of FPI and its paramilitary activities (p. 18). He says that "the military reportedly gave a great deal of support, such as money and military training, to the FPI paramilitary members" ( $p$. 18). He supports his argument by pointing to a number of highranking military officials, such as General Djaja Suarman -the thenJakarta military commander- and General Nugroho Djayoesman - the then-Jakarta police commander- who were seen among the attendants at the FPI's first anniversary celebration.

Pointing to some figures as a proof of their involvement or support to any particular organization, however, sounds too simplistic when the author is unable to accompany his argument with convincing and reliable data. Such an argument can make him fall into a fatal reductionism, where a hard fact is usually conflated with issue and 
rumour. In the context of academic research, the argument must be based on academically sound and reliable data. Otherwise, his sloppiness in making argument may reduce the value of academic ideal of the research.

Another issue he raised is the way the FPI perceives the doctrine of amr bi al-ma'rupwa naby 'an al-munkar (commanding right and forbidding wrong). This doctrine serves as the ideological basis of the FPI to exist and carry out its programs and activities. According to FPI activists, the founding of FPI would be unnecessary unless some other mainstream social-religious organizations such as NU, Muhammadiyah as well as Dewan Dakwah Islamiyah (DDII) assume the responsibility of amr bi al-ma'rupwa naby 'an al-munkar. The fact is that, in their opinion, those organizations are heavily immersed within their own businesses and interests which do not have anything to do with the betterment of Muslim community as a whole. In FPI's opinion, the inability of those organizations to carry out the doctrine is caused by donations given by foreign funding agencies that carry political string (33). In this regard, the author argues that even though this doctrine has actually been applied by several Muslim groups but none has ever made use of it as the FPI has, namely to attract lower-class urban Muslims who have been socially and religiously deprived (p. 31).

In carrying out the doctrine of commanding right and forbidding wrong, the FPI divides the offending places into two categories: naby an al-munkar and amr bi al-ma'rup The category of naby an al-munkar (forbidding wrong) refers to places where the FPI believes kemungkaran (corrupt) activities could be eliminated without resulting in horizontal conflicts. The category of amr bi al-ma'rup (commanding right), however, refers to places that cannot be targeted for the corruption prevention program for this would only lead to horizontal conflicts. Rather, the FPI tends to encourage its people to hold programs focusing on community development and Islamic teaching. Only if the people in such places are not supportive or deny the existence of such kemungkaran, will the FPI target such places as naby 'an al-munkar operation and take necessary measures against them (p. 34).

Through this work, the author believes that the FPI is not antiWest. Like other radical Islamist groups in Indonesia, the fact that FPI is anti-America and Israel is without question. The FPI, for instance, rejected the presence of Israeli delegation during the International Parliamentary Union summit held in Jakarta in 2000. The FPI 
intimidated to deploy itself in Jakarta and blockade Sukarno-Hatta airport if the organizing committee of the conference insisted on inviting the Israeli delegation. The FPI has also been involved in antiAmerican activities, particularly following the US attacks on Afghanistan and Iraq. Together with students, intellectuals, NGOs, and human right activists, the FPI rallied at the US embassy in Jakarta, shouting anti-American slogans.

Nevertheless, the FPI's anti-American stance does not necessarily lead to anti-West mentality. What the group rejects is simply secular ideas and unjust domination of the West over the Muslim world. This domination is only viable due to the fact that the West, led by the US, controls the global political stage by means of international bodies such as the United Nation and the IMF. These bodies, the FPI believes, are no less than the subordinates of US foreign policy (p. 30). As long as the world remains in a state of disequilibrium, the resistance of the Muslims to the West will be never-ending.

Given some interesting issues as debated above, there are some points in this book that can conceptually be debated further. Chief among these is the author's use of the word 'fundamentalism.' He seems to lump the word 'fundamentalism' together with 'Islam' and 'Muslim.' He, for instance, says that 'Islam does not accommodate secularism, which represents the dark side of modernization, thereby making Muslims confused about whether to accept modernization in toto or in part" (p. 11), while neglecting the fact that Islam is multivocal in nature. One should be mindful when talking about a community of religion, i.e. Islam, because it carries various meanings. As Ibrahim Moosa says, there are so many islams (with small 'i') when we talk about 'Islam.'

Second, the author's argument that the FPI is one of the Islamist groups that adopts a substantive way of interpreting the Shariath is theoretically unfounded. In supporting his argument he bases himself on the FPI's proposal of integrating the Shari sath into the national law. In addition, the FPI has suggested that anti-maksiat (unlawful) act be instituted and implemented since maksiat has become a social malady not only for the Muslims but also for non-Muslims (p. 39).

In this context, the author seems to confuse the way the FPI interprets the Shari an and the way the Shari ah should be constituted into national law. It must be admitted that the FPI adopts substantive strategy of instituting the Shari $x_{h}$ into state structure. Instead of 
establishing an Islamic state, the FPI prefers to opt with Islamic values-inspired proposed bills to be instituted and it remains faithful to the framework of Negara Kesatuan Republik Indonesia (NKRI, Unified State of the Republic of Indonesia) (p. 41). The FPI, however, employs conservative literal approach to Islam. It is within this framework that the classification of the FPI under the fundamentalism category is understandable.

The work also seems to suffer from the lack of coherence when linking the background of FPI and the biography of its founder, Muhammad Rizieq Syihab. The author fails to provide an adequate context that links the biography of Syihab to the discussion of FPI. This can be done by, among others, providing a general mapping of radical Islamism that leads to the birth of FPI.

In addition, there are some inconsistencies in using terms such as 'Betawinese' and 'Batavians' (p. 27). There are also inaccuracies in translating some Arabic terms such as 'martyrdom' which is translated as 'shahid'; the correct translation should be 'istishha (looking into martyrdom) (p. 28+30). The author also misspells 'shaykh' with 'shakh' (p. 15). Last but not the least, the author does not provide the book with indices to help readers trace important information in it.

The above criticisms, however, do not reduce the value of the work. It undoubtedly deserves referencing amidst the collection of other works whose focus is radical Islamism in the context of postNew Order Indonesia. In addition to offering some interesting points, it enriches and compliments the perspectives used by preceding works in understanding the subject matter. [] 